\title{
RESEARCH ON PARAMETERS OF THE WORKING AREA ON AN INTERNAL DUMP FOR DEVELOPING OPEN PITS
}

О. О. Анісімов, канд. техн. наук, ст. наук. співроб., orcid.org/0000-0001-8286-7625
Державний вищий навчальний заклад „Національний гірничий університет“, м. Дніпро, Україна, e-mail: ipgpnmu@ ukr.net

\section{ДОСЛІДЖЕННЯ ПАРАМЕТРІВ РОБОЧОЇ ПЛОЩАДКИ НА ВНУТРІШНЬОМУ ВІДВАЛІ ПРИ БУДІВНИЦТВІ ГЛИБОКИХ КАР'СРІВ}

Purpose. Improvement of the method for determining the width of the area for storing overburden at working off the deep open pit and parameters of formation of the internal dump.

Methodology. Analysis of the existing technological schemes for the formation of internal and external dumps in the developing of open pits in Ukraine. For obtaining the results, the following methods were used: statistical and analytical - while processing the main parameters of modern equipment, which is used in the formation of dumps; mining-geometric - while determining the area of possible shearing of overburden rocks in working an excavator on the dump; grapho-analytical - while plotting graphs and analyzing them.

Findings. Modern technological schemes of forming internal dumps with the use of various types of equipment are analyzed, and the parameters of the area of possible displacement rock in forming dumps with the using of excavators are investigated. Dependences of the parameters of the dump on the dimensions of vehicles and working parameters of the dumping equipment are obtained.

Originality. The analytical dependence of the area of possible stripping of overburden rocks is obtained, which takes into account the angle of internal friction of rocks and the formed slope, as well as the height of unloading dump equipment. The method for determining the parameters of the working area needed for forming an internal dump after working off the open pit of the first turn is improved.

Practical value. The creation of dumps in the drawn open space of pits refers to eco- and resource-saving technologies of development. The construction of an internal dump at working off the mining of deep open pits reduces the burden on the environment. The results of the research and the obtained dependencies allow us to improve the methodology for calculating the parameters of the working areas of deep open pits, taking into account the future formation of internal dumps on them. The dimensions of the areas of internal dumps in forming of several tiers have a great influence on the parameters of the dump and the technology of their formation.

Keywords: creating internal dumps, deep open pits, areas for dumps

Introduction. Ukraine has rich mineral and raw material base and it is one of the largest mineral-resource countries of the world. Over 20 thousand deposits and ore occurrences have been discovered on its territory which has 97 kinds of minerals. About 8,000 deposits have been explored, and almost half of deposits have been developed. Production of iron, manganese, uranium, coal, gas, oil and condensate, titanium, zirconium, kaolin, graphite, nonmetallic minerals and others is of the greatest importance. Much of the iron ore deposits are represented steep sheet deposits that have extension on a considerable depth and are developed by deep pits.

Technology of working off the rock of overburden steep dipping layers is the most promising because it allows preparing the ore reserves to the development in an accelerated mode, providing the timely extraction the rock of overburden. It makes it possible to form inner dump in the goaf.

(C) Anisimov O. O., 2018
However, many mining enterprises of Ukraine, leading the mining iron ore on deep pits do not take advantages of developing the rock of overburden steep dipping layers due to the lack of methodological studying of the parameters of the effective formation pit's goaf for further allocation the inner dumps there.

At deep pits, mining operations are done with the separation stages (turn), which take into account the position of the working area for a certain period of time, both in depth and in the plane. In turn, the allotment of steps makes it possible to form inner dumps in the development of mining. Simultaneous extraction of the rocks of overburden and their storage in deep pits allows forming dumps in the goaf for a certain stage of their development and keeping them from the violating large areas of land on the surface.

The width of the non-working platform on the cessation of work on slope of pit usually has small dimensions. In this case, the formation of inner dumps may be only from surface of a deep pit, which complicates their con- 
struction. More effective is the formation of inner dumps tiers. The width of each layer of the tier should be safe and sufficient for accommodation the basic equipment.

The founding of the parameters of platforms for storing the rocks of overburden in the goaf deep iron ore pits by working off slopes steep dipping layers is possible due to the research on technological schemes and parameters of modern equipment.

The above resulted in the actuality of the task and the necessity to study the parameters of a working platform for inner dumps.

Analysis of the recent research and publications. Such scientists as Dryzhenko A., Shapar A., Romanenko A., Simonenko V., Byzov V. and others have dedicated their research studies to technologies of internal storing the rock of overburden in terms of mining deposits in the forming of deep pits.

In the works of A. Romanenko [1] general parameters of internal dumps are determined, calculations for determination the parameters on external dumps are provided, including the above calculations for determination of the width of the working platform. A. Dryzhenko observed that simplifying the organization of forming the internal dump needs to form from surface by one tier on the full depth of working off the pit [2]. When the depth of the pit is larger than the stable height of the stage, the inner dump is formed by the benches taking into account the safety engineering. In the works of V. Symonenko [3] the possibilities of developing non-ore open pits by steep layers with the subsequent formation in a goaf of inner dumps are identified. He emphasizes that the development of non-ore open pits is carried out to a depth of $100 \mathrm{~m}$. The formation of internal dump is carried out by one ledge from the surface. Non-ore open pits of mining rocks have favorable conditions for the formation of internal dump [4]. Analysis of V. Simonenko's research [5] allows to defining also the basic parameters of steep layers which affect on the dimensions of internal dump in its formation from surface.

The provisions for designing internal dumps were developed edited by A. Shapar. These provisions are valid normative documents in Ukraine.

These requirements in the provisions are common and they need improvement.

Analyzing various literature sources for the formation of dumps into the goaf of deep pits the author concludes that it is necessary to improve the existing methods for determining operating parameters of dumps.

Unsolved aspects of the problem. Formation of steep dipping layers prevents the placing rocks of overburden in the goaf during their working out. Thus there is a need for constant increase in volume dump according to the speed of advancing the front of mining operations. The width of the working bench on internal dumps in creating a multi-tiered dump requires additional research studies. First, they depend on dump trucks work. Mostly, they are used in the forming of open pit by steep dipping layers and also together with the equipment which create a dump.

Objectives of the article. The aim is to research the parameters of a working platform while forming an internal dump by tiers with delivery of the rock mass by dump trucks, and improving the method for determining the width of the bench in the storing of overburden.

Presentation of the main research. To achieve the objectives for improving the technological scheme of open mining of steep dipping ore deposits, it is proposed to manage volumes of extraction and storing, to improve transportation scheme, to control the process of mining at simplifying the scheme of working off the deposit and due to this, to decrease the time spent on the opening deposit, to increase its efficiency of mining in general. These can be done by determining sequence of mining deposits together with working off the rock of overburden by steep dipping layers and their storing in the goaf. Formation of steep dipping layers prevents placing the rock of overburden in a goaf simultaneously in working zone. This raises the necessity of constant of its expansion in accordance with the speed the advance of the front of mining operations. New technological scheme of forming goaf the deep open pit by steep dipping excavation layers with the following formation the internal dump in it is proposed (Fig. 1).

The new flow sheet of open mining steep dipping deposits is realized by forming a working area with working off the rock of overburden by steep dipping layers, by transportation minerals to the surface, by division into open pit field to a turn of working off. In the process of working off the first stage, an open pit is formed in de-

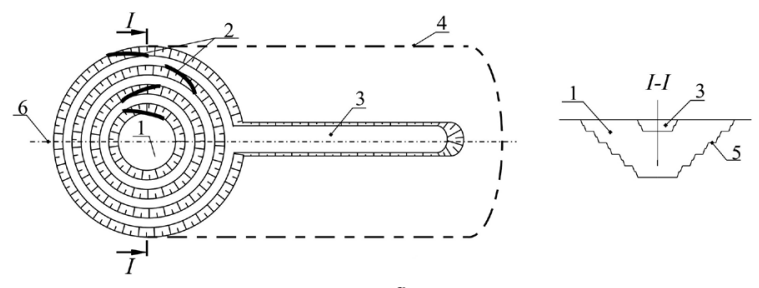

$a$

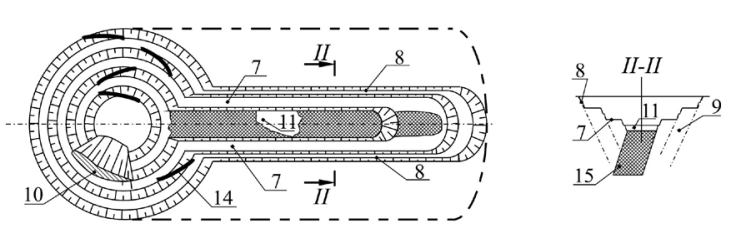

$b$
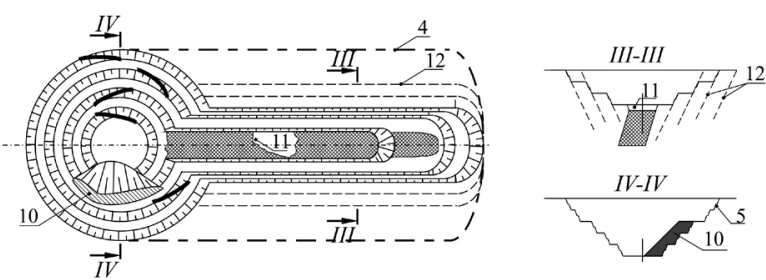

$c$

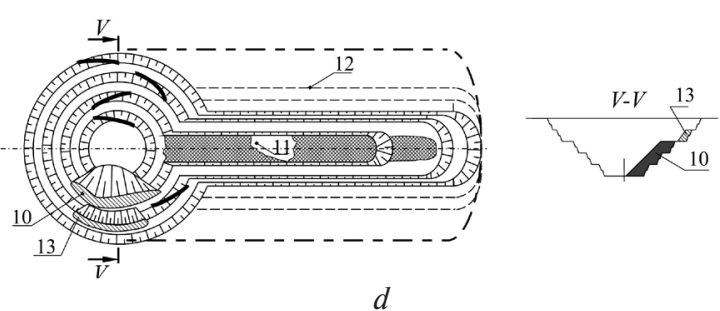

$d$

Fig. 1. Scheme of forming the open pit by steep dipping layers with creating internal dumps of the rock overburden 
sign contours of one of the end face with transport areas on one of the benches, and platforms of future dump on the other bench, with driving the central advance trench along the line stretch of the deposit for working off minerals regarding which the rocks of overburden are removed further by steep dipping layers in open pit of the second stage with moving them to the inner dump of open pit of the first stage.

Implementation of the new process flow design of mining researched deposits is carried out this way. Previously, open pit field is divided into the turn of successive working off. First, in the process of operating the first stage an open pit 1 is formed in design contours 5 with capital crossovers 2 on one of the benches and the platform of future dump - on the other (Fig. 1). In future the open pit of the first stage along the line of stretch deposit 6 is formed within the longitudinal boundaries of the open pit field 4. Transportation of minerals and rock of overburden on the surface in the formation of open pit of the first stage is performed in capital crossovers 2 .

Operating the open pit of the second stage begins with driving the central advance trench 3 along the line stretch of the deposit 6 regarding which operating the rock of overburden by steep dipping excavation layers 9 is carried out. The open pit of the second stage is formed in rocks of overburden by creating of working platforms 7 steep dipping layers within the longitudinal sections 12. Between working platforms 7 temporary non-working areas 8 are formed, which are adjacent ledges by height consisting of two to four units. Disclosure of lower horizons of the open pit of the second stage is provided by a trench 11, which drives in minerals 15 from the respective areas of the open pit of the first stage. Construction of advance trench 11 is done after the preparation and operating of the upper horizons of the open pit of the first stage with working platforms 7 in the rocks of overburden.

Overburden rocks of the open pit of the second stage are moved using transport communications on platforms 7, and capital 2 and temporary crossovers 14 to specially prepared platforms of the open pit where the arrangement of the lower tier 10 of the internal dump is done, and after that, with appropriate forming of platform the lower tier of the rock is piled in the upper tier of the inner dump 13. Construction of temporary crossovers 14 allows reducing the distance of transporting the rocks of overburden to the inner dump 10 in the area between the open pit of the first and the second stages. While developing the operating ore with forming advance trench, the preparation of new reserves to removal is done. Thus, the process of managing volumes of ore extraction and overburden rocks with moving them to the internal dump is realized.

The technical result of the scheme of the development is achieved by apportionment of turns of developing the open pit field. The open pit of the first stage is formed in design contours with crossovers on one of the benches, and the areas of future dump - on the others. Forming of the open pit of the second stage is provided by steep dipping layers of rock overburden with their respective working off top down to the ore. Due to this it becomes possible to conduct advance trench in ore and form the internal multilevel dump in the goaf of the open pit of the first stage. This simplifies transport scheme into the open pit, excludes the moving of overburden rock to external dumps, providing the significant reduction of capital costs, and improves the management of removal of the overburden rocks and minerals.

Physical, mechanical, mining-geological and hydrogeological conditions of formation of a goaf and dumps determine the possibility of storing overburden rock of solid slope directly from the surface or multilevel formation of the internal dumps inside the open pit. For determining a particular technology of dumping works it is necessary to carry out the calculation of stability of the dump for given parameters of its height, the angle of slope with regard to clutch (meshing) of the blocks of rock, angle of internal friction and bulk weight of rocks which are placed. If the coefficient of stability of the internal dump formed at full depth of the open pit is less than 1.15, it is necessary to consider options of multilevel arrangement of overburden rocks, forming thrust prisms, placing overburden rocks of the adjacent benches and other conditions that increase the stability of dumping rocks.

The technology of storing overburden rock by solid slope involves placing them on top the platform of the internal dump and the subsequent moving downwards under gravity and weight of rocks which are placed on top. The disadvantage of the technology of the storing by solid slope is that with the storage of rocks their shrinkage (conglomeration) occurs, which requires several sections for dumping equipment for safety of conducting the dumping works.

Rocks have an angle of slope up to $35^{\circ}$ with small impurities and big detrital rocks available. If the angle of slope open pit bench is less than this value, the storing of overburden rocks is provided by the scheme - Fig. 2, $a$. For the angle of the slope open pit bench being more than $35^{\circ}$ the scheme shown in Fig. 2, $b$ is implemented.

At the arrangement rock by tiers the height of dumping benches is slight, and therefore time of their shrink-

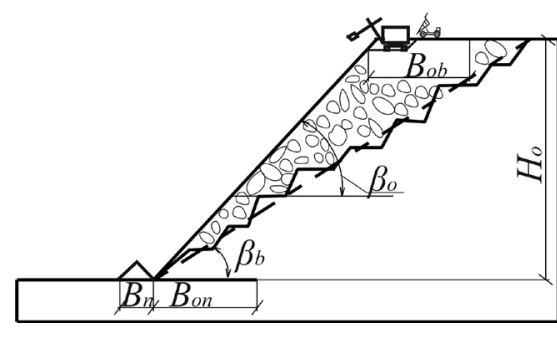

$a$

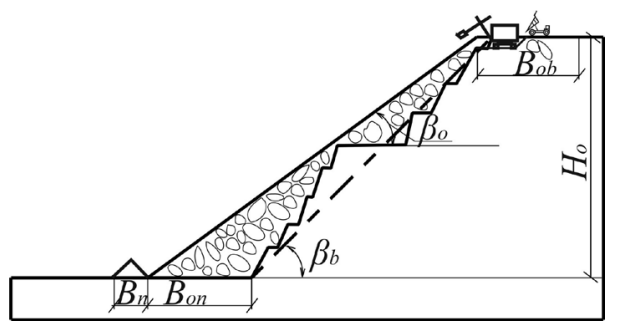

$b$

Fig. 2. Scheme of forming a dump by solid slope with the slope angle smaller than dump slope (a) and with the slope angle larger than dump slope (b) 
age will be less. The number of layers is determined by their height provided stability and undercarriage of open pit. The only drawback of creating several dumping tiers in the produced open pit is that arrangement of each with width $B_{o n}$ should go ahead of the arrangement of upper $B_{o b}$, considering the safe distance between them. It is necessary to build the separation zone of safety on the lower tier or to place a thrust prism on it.

If dumping rocks are unstable and process of their conglomeration is long, it is possible to use the scheme of moving the working equipment of dumping tier from middle to its wings. This scheme allows having a short distance of the moving equipment. During the arrangement of one of the wings, the shrinkage occurs before arranging rocks on the second one, stability of the slope of dump and area for placement of the working equipment increases.

Experience of forming the internal dump at the open pit No.1 PJSC "ArcelorMittal Kryvyi Rih" shows that, as a result of loading slope dump by additional rock mass, a slip of massif occurs after certain time. The initial gap of breaking away is formed at a distance of 4-14 meters from the top edge of the dump. Subsidence of rocks is observed at a depth to $0.5-2.5 \mathrm{~m}$.

The angles of slope of open pit benches and dumps are determined on the basis of analysis of geological, hydrogeological, geotechnical and mining-technical conditions of the deposit, influencing the stability of rocks in slopes. The angle of slope of the internal dumps must be reduced if, according to the condition of the estimated stability, the rate of stability is less than unity. The angle of internal friction of rocks $\rho$, at storage of loosened hard-rocks makes $34-36^{\circ}$. The angle formed by stockpiled overburden rocks is $40-43^{\circ}$ on the average.

The volume of stockpiled rock on the area before the beginning of the shift is conditionally limited by the height of the unloading of equipment, because further placement of rock will be impossible in this sector. Thus, the volume $\left(\mathrm{m}^{3}\right)$ of the formed prism of the slip is

$$
V_{s}=S_{s} \cdot l_{s},
$$

where $S_{s}$ is the square of prism of the slip before the beginning of the shift of the dump, $\mathrm{m}^{2} ; l_{s}$ is the length of the area of storing the rock of overburden.

$$
\begin{gathered}
S_{s}=H_{p}{ }^{2} \operatorname{ctg} \alpha_{o}+ \\
+\frac{1}{2}\left(\frac{2 \cdot H_{p} \cdot \operatorname{ctg} \alpha_{o} \cdot \sin \left(180-\alpha_{o}\right) \sin \rho}{\sin \left(\alpha_{o}-\rho\right)}\right)^{2}\left(\operatorname{ctg} \rho-\operatorname{ctg} \alpha_{o}\right),
\end{gathered}
$$

where $H_{p}$ is the height of the unloading of excavator, m; $\alpha_{o}$ is the angle formed by the rock of overburden, deg.; $\rho$ is the angle of inner friction of the rock of overburden, deg.

The square of the slip is determined according to the graph in Fig. 3, depending on characteristics of rock at an angle of internal friction $34^{\circ}$. This graph shows that knowing the height of the unloading excavators, one can determine the square of the slip.

With the formation of the internal dump, the bigger the height of the unloading of overburden rocks is, the

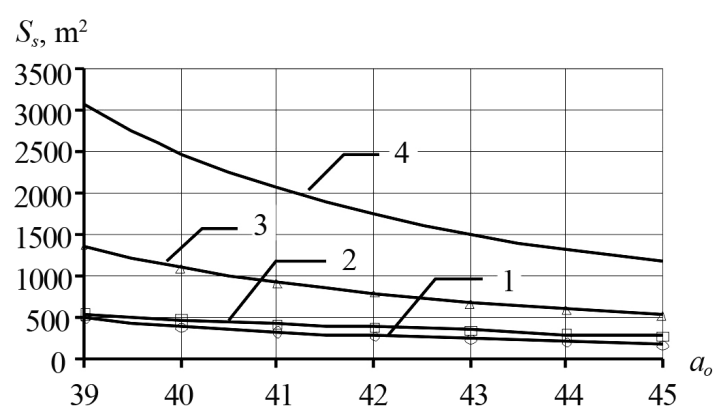

Fig. 3. Graphs of the square Ss of the prism of dump slip depending on the angle of formed dump considering the height of unloading excavators:

$1-H p=6 m ; 2-H p=8 m ; 3-H p=10 m ; 4-H p=15 m$

bigger the cross area, which is formed from these rocks, is. At the arrangement of rocks, placing with an angle of $40^{\circ}$ with the height of unloading $6 \mathrm{~m}$, the cross area of the slip of the dump is $480 \mathrm{~m}^{2}$, with $8 \mathrm{~m}-500 \mathrm{~m}^{2}$, with $10 \mathrm{~m}-1100 \mathrm{~m}^{2}$, with $15 \mathrm{~m}-2490 \mathrm{~m}^{2}$. With the increasing angle of slope dump, the cross area of slip of the dump reduces.

Increase in placement volumes occurs in proportion to the length of respective area. For example, at the placing of inner dump by excavator ES-6/45 for the formation of dump on the area with a length of $400 \mathrm{~m}$, the volumes are stocked in the amount of 2 million $\mathrm{m}^{3}$, with a length of 1000 meters -4.6 million $\mathrm{m}^{3}$, at 1400 meters -6.6 million $\mathrm{m}^{3}$.

The creating of dumping stopes is procured by areas of a length of $200-300 \mathrm{~m}$. If dangerous changes in rocks occur, the dumping works on the working area are stopped and transferred to the next one. After stabilization of shift dumping rocks during 2-3 months, the operations are renewed on the mothballing area. The total front dumping operations should be divided into 3-5 sections. Continuous control of the shift dumping rocks is realized using surveying measurements and visually during all period of work.

Areas of bulldozer dumps are designed along all front of the unloading with cross slope of at least 3 degrees, directed from the edge of the slope to the deep of dump. In the reusable shifts the surface of dump, the number of dumping fronts per unit of equipment is determined by the reserve of $20 \%$.

The dump is built up to the project height by layered storing of rocks. In the process the initial dump is formed with width of surface 50-100 meters. The distance of moving rocks by bulldozers is $4-5 \mathrm{~m}$. Dumping by bulldozers in terms of small areas in width and the forming of the internal dumps on platforms which are left after working off the rock of overburden by steep dipping layers, are the most long-range. Powerful bulldozer technique is maneuverable, allowing for dump creating along an extended front of mining operations.

To implement the dumping by bulldozers, the front is divided into three sections, each of which is formed by a length of at least $100 \mathrm{~m}$ (Fig. 4).

On advance area of the dump along the lower edge of upper bench dump trucks are unloaded no closer than 3 


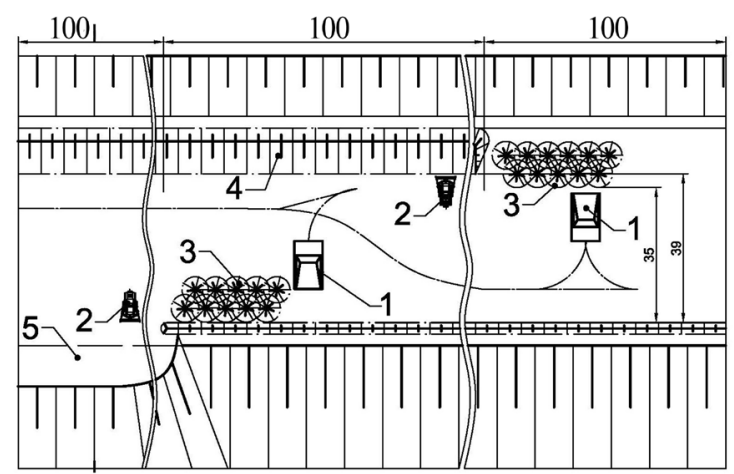

Fig. 4. Scheme of the internal bulldozer dump with delivery of the rock of overburden by dump trucks at the initial stage:

1-dump truck; 2- bulldozer; 3 - dumping cones after unloading by dump trucks; 4 - catching shaft (thrust prism); 5-formed inner dump

meters from it. With accumulation of dumping cones a catching shaft is constructed, which is thrust prism for the upper tier of the dump simultaneously. The width of the catching shaft is 12 meters with its height of $3 \mathrm{~m}$. To save diesel fuel, it is possible to build dumping cones without constructing a catching shaft, but their placing must be the same as that of a catching shaft.

On the second dumping area dump trucks are unloaded for the formation a platform of a dump directly. The third area is intended for pushing overburden rock aside of slope of a dumping layer using a bulldozer. Shrinkage of rocks occurs with the advancing of dumping front and, if necessary rocks are added with further planning.

The width of dumping area for the beginning storing overburden rock should be $(\mathrm{m})$

$$
W_{d}=b_{b}+b_{c s}+T+n_{k} \cdot\left(2 \cdot h_{a} \cdot \operatorname{ctg} \alpha_{n s}\right)+b_{s}+Z,
$$

where $b_{b}$ is the width of the area from the lower edge of slope dump to a catching shaft, $\mathrm{m} ; b_{c s}$ is the width of a catching shaft (thrust prism), $\mathrm{m} ; T$ is the width of transport lane, $\mathrm{m} ; n_{k}$ is the number of dumping cones across the dumping area, unit; $h_{a}$ is the height of cone of the unloading rock by dump truck, $m ; \alpha_{n s}$ is the angle of nature slope of the embankment, degree; $b_{s}$ is the width of the shaft safety, $\mathrm{m} ; Z$ is the width of prism the possible collapse, $\mathrm{m}$.

For ensuring the minimum width of the transport lane in the internal dumping, it should be not less than the radius of the turning of the dump truck. In Fig. 5 the graph gives allows determining the minimum width of the area in bulldozer dumping taking into account the working dimensions of dump trucks of different manufacturers.

The layered internal dumping is carried out sequentially on the area, starting with the lower group of benches. The formation of dumping tiers on the upper areas is begun after the construction and advance of the dumping front on the lower areas. Construction of the upper tier of the dump occurs after the distance $B_{\min }$ is provided with the corresponding projection of the inner dump from the upper edge of the area of the upper tier to the bottom with the additional construction of three crests of the catching shaft (Fig. 4), m.

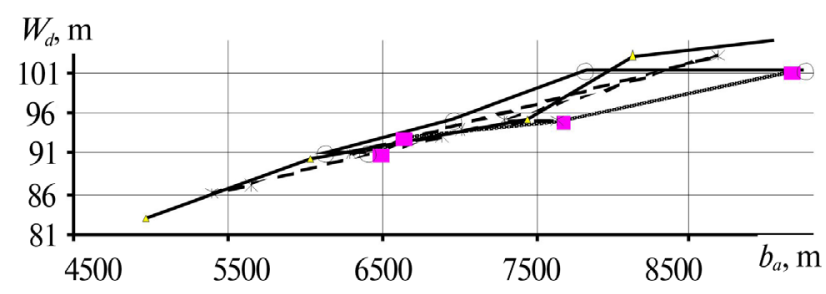

Fig. 5. Width of the dump area, depending on the radius of the turning of the dump truck at bulldozer dumping:

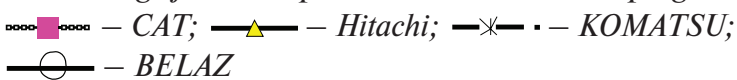

$$
B_{\min }=H_{t} \cdot\left(\operatorname{ctg} \alpha_{d}-\operatorname{ctg} \alpha_{l}\right)+3 \cdot b_{c},
$$

where $H_{t}$ is the height of the dumping tier (group of benches in the steep dipping layer), $\mathrm{m} ; \alpha_{d}, \operatorname{ctg} \alpha_{1}$ are the angles of slopes of the dump and steep dipping layer, deg.; $b_{c}$ is the width of the crest of the catching shaft, $\mathrm{m}$.

The lower tier is formed with the width of the dumping stope from 5 to $10 \mathrm{~m}$. The three crests of the catching shaft play the role of a damping pillow that absorbs the energy of movement of the blocks of the rock, which roll out from the upper dumping tier. The volume of the storable rock from the upper area at the initial stage of the formation of the dumping tier will be, $\mathrm{m}^{3}$

$$
\begin{gathered}
V_{t}=\left(H_{t} \cdot\left(\operatorname{ctg} \alpha_{d}-\operatorname{ctg} \alpha_{l}\right) \cdot l_{y o}-\right. \\
-\frac{1}{2} h_{s} \cdot b_{s} \cdot\left(\frac{H_{t} \cdot\left(\operatorname{ctg} \alpha_{d}-\operatorname{ctg} \alpha_{l}\right)}{b_{s}}\right) \cdot l_{y o},
\end{gathered}
$$

where $l_{y o}$ is the length of the dumping front, $\mathrm{m} ; h_{s}$ is the height of the catching shaft (thrust prism), $\mathrm{m}$.

Thus, rational application of the bulldozer dumping is achieved on account of the separation of the dumping front on areas, the formation of crests of catching shafts and the construction of a bulldozer dump by the tiers which are formed from the lower area of steep dipping layer gradually with inclusion in the process of dumping the above located areas.

The technology of excavation dumping is described in detail in [1]. For delivering rocks by trains, the fleet of excavating excavators is adjusted according to the number of dumping stub tracks on the surface near the open pit. The length of the dumping stub tracks is taken depending on the specific conditions of exploitation and may change from 0.5 to $2.0 \mathrm{~km}$, averaging $1.0-1.5 \mathrm{~km}$. The step of moving the railways on the dumps should be taken depending on the type of dumping equipment: with excavators EKG-4.6B, EKG-5A - 21 m, EKG-8I, EKG-10 27 m, EKG-12.5-15 - 34 m, EKG-20 - 40m, ES-6/40 $60 \mathrm{~m}, \mathrm{ES}-10 / 70-110 \mathrm{~m}$. The use of trains is possible only on the upper tier of the inner dump. The use of dump trucks is expedient for forming tiers on the lower horizons.

The scheme of the formation of an internal excavation dump with the use of dump trucks is shown in Fig. 6. While using excavators such as a mechanical shovel, the scheme envisages the formation of the upper unloading area and the bottom where the overburden rocks are stored temporarily and the excavator is placed. For the advancing 
of dumping layer, the upper area is formed by a bulldozer, and the lower one is formed by an excavator.

Unlike the known schemes, this scheme of forming steep dipping layers requires the placement of an additional shaft of safety on the upper dumping area, along the upper benches which are formed by steep dipping layers.

The width of the dumping area depends on the working parameters of the equipment which is involved in the formation of the internal dump (Fig. 7).

An increase in clearance radius of the dump truck assumes a proportional increase in the width of the area in the excavation dumping.

For storing rocks of overburden as an alternative variant of excavation and bulldozer method of filling the open pit, a spreader with parallel movement along the front of the dumping works is considered. A technological scheme is proposed, whose principle is in the overloading overburden rocks from road transport to the spreader through a loading hopper with a crusher and its subsequent movement in a dump by conveyor (Fig. 8) [6].

On the prepared area a temporary embankment of rocks the factions $0-150 \mathrm{~mm}$ is arranged. Dump truck drives at a trestle along the embankment, unloads the rock in a reloading hopper with a capacity of at least $75 \mathrm{~m}^{3}$. In the bottom of the bunker, a crusher and a lamellar feeder are installed, with the help of which the dump mass is transported to the belt conveyor. Rock is moved into the goaf of the open pit by the belt conveyor and is stored in the inner dump. The formation of a temporary embankment is carried out by a front wheel loader with a capacity of bucket $5-6 \mathrm{~m}^{3}$.

Moving the installation is carried out with the help of the same loader on specially designed reinforced concrete slabs. Within one hour of operation such a unit can take up to 6 dump trucks. Its estimated productivity is 957 thousand $\mathrm{m}^{3}$ /year. The installation has a mass by an

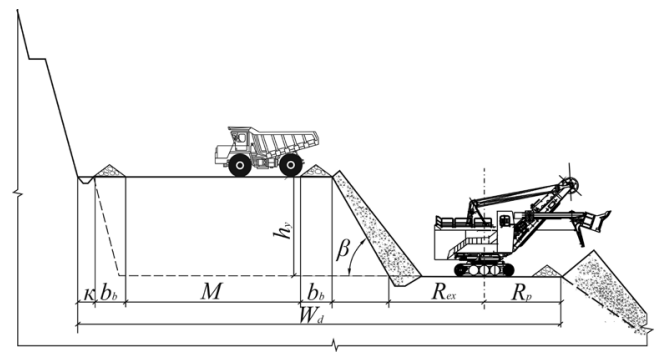

Fig. 6. Scheme of internal excavation dumping for the formation of tiers

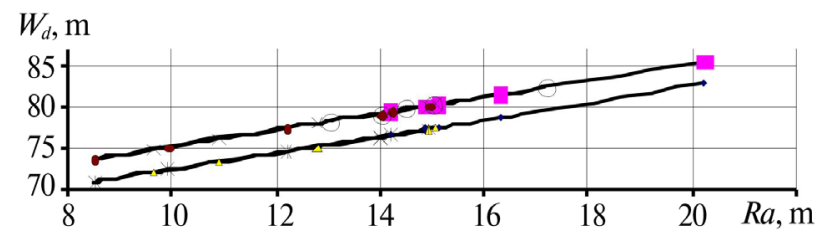

Fig. 7. Width of the dumping area depending on the radius of turning of the dump trucks at excavation dumping:

$\neg-C A T\left(E K G-6,3 y_{c}\right) ; \longrightarrow-$ Hitachi $\left(E K G-6,3 y_{c}\right)$; *-KOMATSU $(E K G-6,3 y) ;--B E L A Z(E K G-$ 18); - - CAT(EKG-18); $\nVdash-H i t a c h i\left(E K G-6,3 Y_{c}\right)$; $\sim-\operatorname{KOMATSU}($ EKG-18) order of magnitude smaller than an excavator. It can be managed remotely.

The working area for the formation of a dump by an experimental conveyor installation consists of an area with possible shift of rocks, an embankment under the trestle, the width of the safety shaft, and the traffic lane of dump trucks. The width of the working area $(\mathrm{m})$ under given conditions is determined by the formula

$$
W_{d}=Z_{n}+C+W_{e}+W_{d t}+b_{k},
$$

where $Z_{n}$ is the prism of possible shift, $\mathrm{m}$; $C$ is the distance from the an trestle embankment to the traffic lane; $W_{e}$ is the width of the strip under the embankment of trestle, $\mathrm{m} ; W_{d t}$ is the width of the traffic lane, $\mathrm{m} ; b_{k}$ is the width of the fit ditch, m;

$$
W_{e}=W_{d}+2 B_{b}+2 C+2 H_{e} \operatorname{ctg} \beta,
$$

where $W_{d}$ is the width of the road of an trestle embankment, $\mathrm{m} ; H_{e}$ is the height of an trestle embankment, $\mathrm{m}$; $\beta$ is the angle of slope of an trestle embankment, $d$.

Moving the temporary embankment of the trestle is carried out at a distance of $10 \mathrm{~m}$, which corresponds to the step for storing $1050 \mathrm{~m}^{3}$ of the rock. The width of the dumping area will change with the change in the parameters of transport equipment for the formation of the internal dump by a spreader (Fig. 9).

Conclusions and recommendations for further research. In the conditions of working off overburden rocks by steep

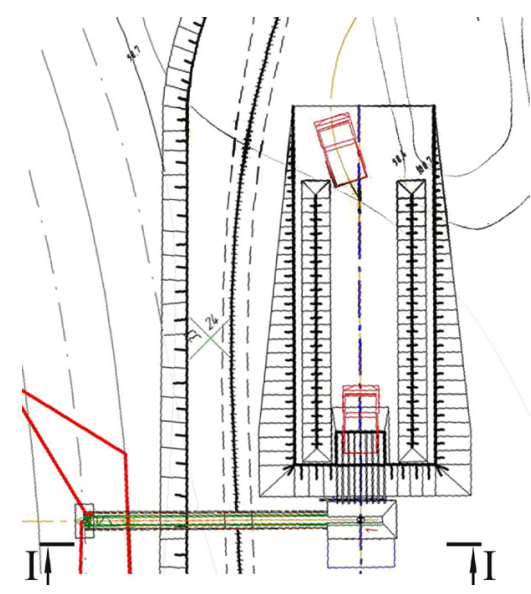

Fig. 8. An installation for storing overburden rocks with the use of a spreader (top plan view)

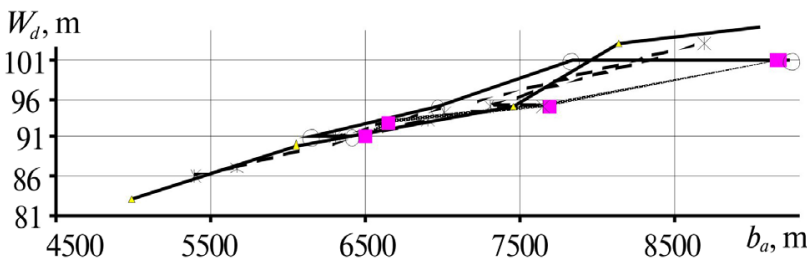

Fig. 9. The width of the dumping area, depending on the width of the dump trucks at dumping by an experimental console spreader:

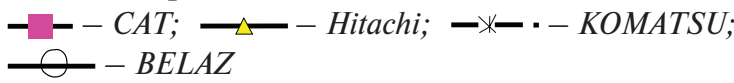

ISSN 2071-2227, Науковий вісник НГУ, 2018, № 1 
dipping layers for internal dumping from the surface of an open pit, the most suitable equipment includes a dragline excavator, a mechanical shovel with extended working equipment or spreaders with a preliminary overloading and crushing of the overburden rocks. It is recommended to do inner open pit storage of overburden rocks by tiers with delivery of dump trucks using bulldozers.

Moving of the rock mass is carried out by dump trucks into the open pit in working off steep dipping layers. The width of the dumping area during bulldozer and excavation dumping will depend on the radius of the turning of the dump trucks and working parameters of dumping equipment. The width of the dumping area, taking into account the embankment formed for the driving of an dump truck, depends on its width and dimensions of dumping console at dumping with the help of an experimental spreader.

According to Figs. 5, 7 and 9 the dependences of the dumping working area on the dimensions of the vehicles and the working parameters of the dumping equipment were obtained (Table).
Use of the above mentioned dependencies allows determining the width of the inner dumping area and preparing them for placement of equipment and work with the formation of the internal dump, accordingly, in the working off steep dipping layers in advance.

Research studies on the parameters of the working area at internal dumping by tiers with the delivery of rock mass by dump trucks, and the improvement of the method for determining the width of the area during the storing of overburden rock allow using the obtained dependencies in the designing deep open pits.

Further development of the aforementioned methodology for the technological scheme of working off an open pit field by steep dipping layers may be determined in the formation of an internal dump with a longitudinal or diagonal front of the dumping works or in the introduction of new types of equipment. The obtained dependencies will allow conducting further research on the improvement of technological schemes for the formation of internal dumps in deep open pits.

Table

Width of areas in the internal creating of dump

\begin{tabular}{|c|c|c|c|}
\hline Dump truck & Formula of definition of the width of dump, $m$ & $\begin{array}{l}\text { Approximation } \\
\text { index }\end{array}$ & Dependence \\
\hline & \multicolumn{3}{|c|}{ Bulldozer creating of dump } \\
\hline CAT & $\begin{array}{l}W_{d}=-0.1202 \cdot R_{a}^{2}+5.8643 \cdot R_{a}-4.8766 \\
R_{a}-\text { the radius of the turning of dump truck }\end{array}$ & 0.9971 & polynomial \\
\hline Hitachi & $W_{d}=1.8512 \cdot R_{a}$ & 0.996 & line \\
\hline COMATSU & $W_{d}=0.0341 \cdot R_{a}^{2}+0.9689 \cdot R_{a}+36.323$ & 0.9821 & polynomial \\
\hline \multirow[t]{2}{*}{ BELAZ } & $\mathrm{W}_{\mathrm{d}}=0.0474 \cdot R_{a}^{2}+0.2586 \cdot R_{a}+42.311$ & 0.9286 & polynomial \\
\hline & \multicolumn{3}{|c|}{ Excavation creating of dump } \\
\hline \multirow{3}{*}{$\begin{array}{l}\text { CAT } \\
\text { Hitachi } \\
\text { COMATSU } \\
\text { BELAZ }\end{array}$} & $W_{d}=R_{a}+62.4(\mathrm{EKG}-6,3 \mathrm{Y})$ & 1.0 & line \\
\hline & $W_{d}=R_{a}+65.2(\mathrm{EKG}-18)$ & 1.0 & line \\
\hline & \multicolumn{3}{|c|}{ Experimental spreader } \\
\hline CAT & $\begin{array}{l}W_{d}=4 \cdot 10^{-7} \cdot b_{a}^{2}-0.0033 \cdot b_{a}+94.981 \\
b_{a}-\text { width of dump truck }\end{array}$ & 0.9751 & polynomial \\
\hline Hitachi & $W_{d}=-1 \cdot 10^{-7} \cdot b_{a}^{2}-0.0075 \cdot b_{a}+49.349$ & 0.996 & polynomial \\
\hline COMATSU & $W_{d}=3 \cdot 10^{-7} \cdot b_{a}^{2}-0.001 \cdot b_{a}+72.818$ & 0.9782 & polynomial \\
\hline BELAZ & $W_{d}=-2 \cdot 10^{-7} \cdot b_{a}^{2}+0.0292 \cdot b_{a}-26.61$ & 0.9574 & polynomial \\
\hline
\end{tabular}

\section{References.}

1. Romanenko, A., Klesnikov, D., Gritsina, A., Udod, E. and Protasov, V., 2012. Working off magnetite quartzites with the using technology of internal creating of dump. Krivoy Rog: Publisher FL-P Chernyavsky D.

2. Dryzhenko, A., Shustov, A. and Adamchuk, A., 2016. Prospects for future mining of steep iron-ore deposits in the context of Kryvbas. Metallurgical and Mining Industry, 10, pp. 46-52.
3. Symonenko, V., Pavlichenko, A., Chernyayev, O., Gritsenko, L. and Savenkov, S., 2016. Technological aspects of ecological safe development of non-ore open pits at their elimination and conservation. Bulletin of the National University of Water Management and Nature Management. Technical sciences, 2, pp.148-158.

4. Chernyaev, O., 2017. Systematization of the hard rock non-metallic mineral deposits for improvement of their mining technologies. Naukovyi Visnyk Natsionalnoho Hirnychoho Universytetu, 5, pp. 11-17. 
5. Symonenko, V., Cherniaiev, O. and Hrytsenko, L., 2016. Organization of non-ore deposits development by steep excavation layers. Mining of Mineral Deposits, 10(4), pp. 68-73. 6. Anisimov, O., 2015. Technology of construction and development of deep open pits. Dnepropetrovsk: National Mining University.

Мета. Удосконалення методики визначення ширини площадки для складування розкривних порід при відпрацюванні глибокого кар'єру й параметрів формування внутрішнього відвалу.

Методика. Аналіз існуючих технологічних схем формування внутрішніх і зовнішніх відвалів при розробці кар'єрів України. Для отримання результатів використалися методи: статистичний та аналітичний - при обробці головних параметрів сучасного обладнання, що використовується при формуванні відвалів; гірничо-геометричний - при визначенні площі можливого зрушення порід розкриву; графоаналітичний - при побудові графіків і їх аналізі.

Результати. Проаналізовані сучасні технологічні схеми формування внутрішніх відвалів із застосуванням різного типу обладнання, досліджені параметри площі можливого зсовування порід при формуванні відвалів із застосуванням екскаваторів. Отримані залежності параметрів відвальної робочої площадки від габаритів транспортних засобів і робочих параметрів відвального обладнання.

Наукова новизна. Отримана аналітична залежність площі можливого зсовування порід розкриву, що враховує кут внутрішнього тертя порід і формованого укосу, а також висоту розвантаження відвального устаткування. Удосконалена методика визначення параметрів робочої площадки, необхідної для формування внутрішнього відвала після відпрацювання кар'єру першої черги.

Практична значимість. Створення відвалів у виробленому просторі кар'єрів відноситься до еколого- й ресурсозберігаючих технологій розробки. Будівництво внутрішнього відвалу при відпрацюванні глибоких кар'єрів знижує навантаження на навколишнє середовище. Результати дослідження та отримані залежності дозволять удосконалити методику розрахунку параметрів робочих площадок глибоких кар'єрів з урахуванням майбутнього формування внутрішніх відвалів на них. Розміри площадок внутрішніх відвалів при формуванні декількох ярусів мають великий вплив на параметри відвалу й технологію їх формування.

Ключові слова: внутрішні відвали, глибокі кар’єри, площадки для відвалів
Цель. Усовершенствование методики определения ширины плошадки для складирования вскрышных пород при отработке глубокого карьера и параметров формирования внутреннего отвала.

Методика. Анализ существующих технологических схем формирования внутренних и внешних отвалов при разработке карьеров Украины. Для получения результатов использовались методы: статистический и аналитический - при обработке основных параметров современного оборудования, которое используется при формировании отвалов; горногеометрический - при определении площади возможного сдвижения пород вскрыши при работе экскаватора на отвале; графоаналитический - при построении графиков и их анализе.

Результаты. Проанализированы современные технологические схемы формирования внутренних отвалов с применением различного типа оборудования, исследованы параметры площади возможного сдвижения пород при формировании отвалов с применением экскаваторов. Получены зависимости параметров отвальной рабочей площадки от габаритов транспортных средств и рабочих параметров отвального оборудования.

Научная новизна. Получена аналитическая зависимость площади возможного сдвижения пород вскрыши, которая учитывает угол внутреннего трения пород и формированного откоса, а также высоту разгрузки отвального оборудования. Усовершенствована методика определения параметров рабочей площадки, необходимой для формирования внутреннего отвала после отработки карьера первой очереди.

Практическая значимость. Создание отвалов в выработанном пространстве карьеров относится к эКолого- и ресурсосберегающим технологиям разработки. Строительство внутреннего отвала при отработке глубоких карьеров снижает нагрузку на окружающую среду. Результаты исследования и полученные зависимости позволяют усовершенствовать методику расчета параметров рабочих площадок глубоких карьеров с учетом будущего формирования внутренних отвалов на них. Размеры площадок внутренних отвалов при формировании нескольких ярусов имеют большое влияние на параметры отвала и технологию их формирования.

Ключевые слова: внутренние отвалы, глубокие карьеры, площадки для отвалов

Рекомендовано до публікації докт. техн. наук Б.Ю. Собко. Дата надходження рукопису 10.01.17. 